\title{
Decision Support System for Selecting Banjar Restaurant in Banjarmasin City Using Simple Additive Weighting Method
}

\author{
Juhriyansyah Dalle ${ }^{1 *}$, Windarsyah², Rasyid Ridho ${ }^{3}$, \\ Information Technology Department, Universitas Lambung Mangkurat, Banjarmasin, Indonesia \\ ${ }^{2}$ Informatics Engineering Department, Universitas Muhammadiyah Banjarmasin, Indonesia. \\ ${ }^{3}$ Allumny of Information Technology Department, Universitas Lambung Mangkurat, Banjarmasin, Indonesia
}

\begin{tabular}{|c|c|}
\hline ARTICLE INFO & A B S T R ACT \\
\hline \multirow[t]{2}{*}{$\begin{array}{l}\text { Received: OI-I2-20I8 } \\
\text { Revised: 29-I2-2018 } \\
\text { Accepted: 30-I2-20I8 } \\
\text { Keywords: } \\
\text { Decision Support System } \\
\text { (DSS), Simple Additive } \\
\text { Weighting (SAW), Banjar } \\
\text { Restaurant }\end{array}$} & $\begin{array}{l}\text { This study aims to build a decision support system (DSS) application for selecting } \\
\text { Banjar restaurant using website-based Simple Additive Weighting (SAW) method. } \\
\text { This application can be accessed by all users, both via smartphone and } \\
\text { laptop/computer. Users can access the application to assist the selection of Banjar } \\
\text { restaurant based on the weighting of the required criteria. Data of Banjar } \\
\text { restaurants was obtained from the Tourism Office of South Borneo Province. } \\
\text { Decision support system for selecting Banjar restaurant was built using XAMPP as } \\
\text { a server, MySQL as a database, HTML (Hypertext Markup Language), JavaScript } \\
\text { framework using jQuery, PHP framework (Hypertext Preprocessor) using Laravel, } \\
\text { and CSS framework (Cascading Style Sheet) using Bootstrap. Meanwhile, the } \\
\text { system development used was waterfall method. The parameters used to choose a } \\
\text { Banjar restaurant were in terms of facilities, opening time, price, variety of menus, } \\
\text { and capacity. The result of this research is a decision support system application } \\
\text { that can provide results in the form of Banjar restaurant alternatives based on } \\
\text { rankings from the highest to lowest values generated from calculations using SAW } \\
\text { method. This system is also equipped with distance that appears automatically } \\
\text { between the user's location and the restaurant, and time that adjusts and shows } \\
\text { which restaurants are open at the accessing time. From the analysis results of the } \\
\text { Calculation Score Interpretation (CSI) average, the results of users' responses in } \\
\text { general from the Tourism Office, tourists, or prospective consumers, stated that the } \\
\text { system is very suitable to be used as a reference in selecting Banjar restaurant in } \\
\text { Banjarmasin City, with an } 88.8 \% \text { CSI. }\end{array}$ \\
\hline & $\begin{array}{l}\text { (C) } 2018 \text { The Authors. Journal of K6, Education, and Management (j-K6EM). ISSN: } 2580-2135 \text {. } \\
\text { Published by Graduated Program of Educational Management, Universitas Lambung } \\
\text { Mangkurat, Banjarmasin, Indonesia. This is an open access article under the open journal } \\
\text { systems. }\end{array}$ \\
\hline
\end{tabular}

*Author correspondence: Juhriyansyah Dalle; E-mail: j.dalle@ulm.ac.id 


\section{Introduction}

Banjarmasin has the narrowest area in South Borneo province, which is $72.67 \mathrm{KM} 2$ or only $0.19 \%$ of South Borneo region (Rijani, 2015). Nevertheless, various kinds of tourist attraction can be found in this city, such as natural, cultural, historical, religious and culinary tourist attractions. Tourist attractions in Banjarmasin city attract both domestic and foreign tourists to come for a visit. Domestic tourists are tourists or people who are the residents of the country visiting a tourist attraction. Meanwhile, foreign tourists are tourists who come from abroad for visiting a tourist attraction. These tourists are usually called foreigners.

After visiting several tourist attractions in Banjarmasin, the tourists usually want to take a break while enjoying Banjar authentic meal or food. Banjar food are food originating from Banjar region which recipe are inherited from their ancestors. There are various kinds of Banjar food such as Soto Banjar, nasi kuning Banjar, lontong orari, ketupat kandangan, mandai, etc. Banjar food has a distinctive taste that makes it acceptable to the community. In this moment, tourists would like to go on a culinary tour by looking for a Banjar restaurant. However, it is difficult for the majority of tourists to find information about Banjar restaurants, because generally, they are looking for restaurants based on the criteria.

Based on interview with several domestic tourists, they admitted that it was difficult to find an authentic Banjar food based on the criteria. It becomes a problem not only for tourists but also for the people of Banjarmasin city. They are still confused and need information about Banjar restaurants. They usually obtain information from the word of mouth and the internet. However, the results of utilizing the internet to search information about Banjar restaurants are not always satisfactory because there are only a few restaurant data on the site and it is not enough to facilitate people in making decision.

It becomes a problem that needs a solution. Therefore, a Decision Support System (DSS) is needed for selecting restaurants that provide convenience for tourists or prospective consumers in choosing a place based on the criteria. This system will contain data of several Banjar restaurants in Banjarmasin City area that are recommended by the South Borneo Provincial Tourism Office. In addition to containing Banjar restaurants information, this system also facilitates users to select restaurants based on the criteria. By including weight values on the existing criteria, the system will provide Banjar restaurant alternatives that are needed by the user. Then, this system is also equipped with distance that appears automatically between the user's location and the restaurant as well as time that adjusts and shows which restaurants are open at the accessing time. This is what distinguishes DSS for selecting Banjar restaurant with the other existing restaurant websites.

DSS is a system that is able to provide problem solving and communicating abilities with semistructured and unstructured conditions. This system is used to facilitate in decision making in semi-structured and unstructured situations, in which no one knows for sure how the decision should be made (Afnariuss, et. al., 20I4). To make DSS, there are several methods that can be used, one of which is the SAW (Simple Additive Weighting) method. SAW is one of methods in DSS handling data cost and benefit simultaneously. SAW method is a method used to find weighted sums of performance ratings on each alternative on all attributes (Muliady, et. al., 2013).

Therefore, based on the above problem, the solution is creating a website-based system that can provide information to facilitate users. Thus, the title of this paper is "Decision Support System for Selecting Banjar Restaurant in Banjarmasin City Using Simple Additive Weighting Method".

\section{Literature Research}

This section explains related literature study and research.

\section{I. Decision Support System}

Decision support system (DSS) is part of computer-based information system (including knowledge system) which is used to support decision making in an organization or company. DSS is a combination of individual intelligence sources with the ability of components to improve the quality of decisions. Decision Support System is also a computer-based information system for 
management decision-making dealing with semistructural problems (Keen \& Morton, I978).

Decision support system is also defined as a computer system that is able to provide problem solving and communicating abilities for semistructured problems. Specifically, DSS is defined as a system that supports the work of a manager or group of managers in solving semi-structured problems by providing information or proposals towards certain decisions (Sugiyono, 2008).

\subsection{Simple Additive Weighting Method}

SAW method is a method known as weighted sum method. The basic concept of SAW method is to find weighted sum of performance ratings on each alternative on all attributes. SAW method requires the process of normalizing the decision matrix $(\mathrm{X})$ to a scale that can be compared with all available alternative ratings. SAW method recognizes 2 (two) attributes, namely benefit and cost criteria. The fundamental differences between these two criteria is the selection of criteria in making decisions (Kusumadewi, 2006).

The steps for solution are (Kusumadewi, 2006):

I. Determining the alternatives, namely Ai.

Description:

$\mathrm{Ai}=$ Alternative, in this system it is called the restaurant.

2. Determining the criteria to be used as a reference in decision making, namely $\mathrm{Cj}$.

Description:

$\mathrm{C}_{\mathrm{j}}=$ Criteria, in this system it is called the DSS criteria such as facilities, price, menu variation, capacity.

3. Providing the match rating value of each alternative on each criterion.

4. Determining the preference weight or level of importance $(\mathrm{W})$ of each criterion.

$\mathrm{W}=[\mathrm{WI}, \mathrm{W} 2, \mathrm{~W} 3, \ldots, \mathrm{Wj}]$

Description:

$\mathrm{Wj}_{\mathrm{j}}=$ Weight value of each criterion, in this system the weight value is input according to user input.

5. Making a match rating table of each alternative on each criterion.

6. Making a decision matrix $(\mathrm{X})$ which is formed from a match rating table of each alternative on each criterion. The $x$ value of each alternative
(Ai) on each criterion $\left(\mathrm{C}_{j}\right)$ has been determined, in which, $i=1,2, \ldots m$ and $j=1,2 \ldots n$.

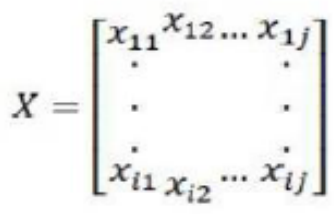

Description:

$\mathrm{X}=$ Decision matrix, containing $\mathrm{x}$ value of each alternative (Ai) on each determined criterion $(\mathrm{Cj})$.

$\mathrm{xij}=$ Match rating value that belongs to each criterion, for example I, 2, 3, 4, or 5 .

7. Normalizing the decision matrix by calculating the calculated performance rating (rij) of $\mathrm{Ai}$ alternative to $\mathrm{C}_{j}$ criteria.

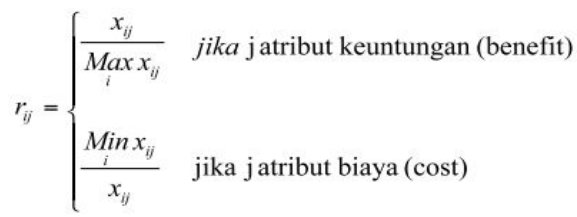

Description:

rij $=$ Normalized performance rating value, depending on the attributes of benefit or cost, in this system, criteria include facilities, menu variation, capacity including benefit attributes, while price is cost attributes.

Max xij = the greatest value of each criterion.

Min $x i j=$ the smallest value of each criterion.

Benefit $=$ the greatest value is the best.

Cost $=$ the smallest value is the best.

a. It is considered as benefit criteria if the value provides benefit for decision makers, otherwise it is considered as cost criteria if it incurs cost for decision makers.

b. If it is in the form of benefit criteria, the value is divided by the value of each column, while for the cost criteria, the value of each column is divided by the value.

8. The results of normalized performance rating (rij) form normalized (R) matrix.

$$
R=\left[\begin{array}{cccc}
r_{11} & r_{12} & \ldots & r_{1 j} \\
\cdot & & & \cdot \\
r_{i 1} & & & \\
r_{i 2} & \ldots & r_{i j}
\end{array}\right]
$$


Description:

$\mathrm{R}=$ Normalized matrix, containing results of normalized performance rating value (rij).

$\mathrm{rij}=$ Normalized performance rating value.

9. The final result of preference value $(\mathrm{Vi})$ was obtained from the sum of multiplication of normalized matrix $(\mathrm{R})$ elements with preference weight (W) corresponding to the matrix column element (W).

$$
V_{i}=\sum_{j=1}^{n} W_{j} r_{i j}
$$

A larger result of $\mathrm{Vi}$ value calculation indicates that the Ai alternative is the best alternative.

Description:

$\mathrm{Wj}=$ Weight value of each criterion, in this system it would be input according to user input

$\mathrm{V}_{\mathrm{i}}=$ Ranking for each alternative (preference value), restaurant that has the highest value is considered the best solution.

$\mathrm{Ai}=$ Alternative, in this system it is called the restaurant.

\subsection{Related Research}

This research refers to researches that had been conducted before. There are several researches related to this research:

I. Decision Support System for Determining Leading Travel Attractions in Palembang City.

2. Design of Yogyakarta Culinary DecisionMaking Support System.

3. Decision Support System for Selecting Culinary Places using TOPSIS Method along with Geographical Information in Malang City.

4. Implementation of Simple Additive Weighting Method in Teacher Certification Decision Making System.

5. Decision Support System for Selecting Residential House Using Simple Additive Weighting (SAW) Method (Case Study: Samarinda City).

\section{Analysis}

\section{I. System Analysis}

System analysis was the initial stage in developing a system. In this stage, the researchers shall know in advance the existing or running system, followed by formulating the research problem. In this research, there was still no decision support system that can help tourists visiting Banjarmasin city in terms of making decisions regarding Banjar restaurant that meets their preferences according to existing criteria.

\subsection{Problem Analysis}

The next stage was analyzing the problem. In the previous system analysis, it had been mentioned that the problem in this research was the lack of decision support system that can help tourists or prospective consumers in selecting Banjar restaurant based on the criteria and providing information about Banjar restaurants. Therefore, the system to be created will facilitate tourists or prospective consumers in selecting Banjar restaurant while providing information about Banjar restaurants. Consequently, tourists can find out and pay a visit.

\subsection{Knowledge Source Analysis}

The last stage was knowledge source analysis. The knowledge sources in this research were form literature studies on decision support system and Simple Additive Weighting (SAW) method from journals, theses or final assignments, as well as articles written by previous researchers. In addition, this research also included direct observation and interview to parties involved in this research.

\section{Software Development}

\section{I. Software Analysis and Design}

At the data analysis stage, the researcher obtained data on Banjar restaurants in Banjarmasin city by conducting direct interview to the department of tourism of South Borneo. After obtaining the data, the criteria to be used as parameters or material considerations in decision making were determined. The next step was to determine the suitability rating of each alternative (restaurant) on each criterion. Furthermore, decision matrix was made based on the criteria, then the matrix was normalized based on the equation that was adjusted to the type of attribute, namely the benefit and cost attributes, so that the normalized matrix can be obtained. 
The final results were obtained from the ranking process, namely the sum of the normalized matrix multiplications with the weight values of the criteria input by the user, so that the ranking from the highest to the lowest was obtained as an alternative choice.

The system design to be made can be seen in Picture I below.

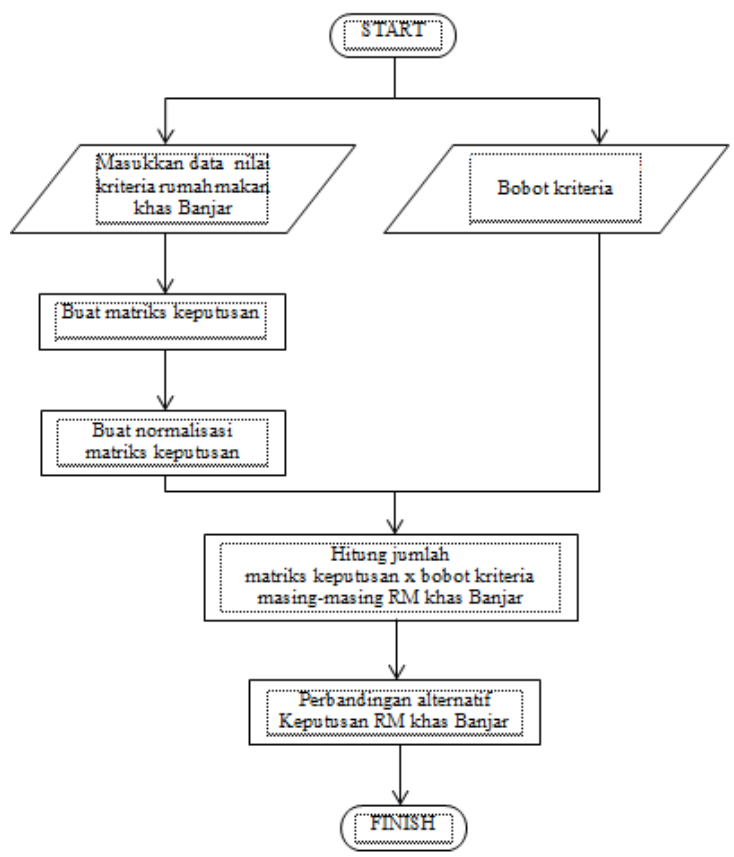

Picture I. System Design

In Picture 3.4, the stages of system design with the SAW method in this research are explained. The first step was inputting data on the criteria for Banjar restaurant and determining the criteria for the weight respectively. After inputting the value of these criteria, decision matrix was made, followed by normalizing the decision matrix.

The next stage was calculating the sum by multiplying the decision matrix to the weighting criteria of each restaurant. Consequently, an alternative comparison of Banjar restaurant decision was obtained in the form of ranking. Finally, the process was complete.

Picture 2 below is the use case diagram (admin) that explains admin capabilities in the system.

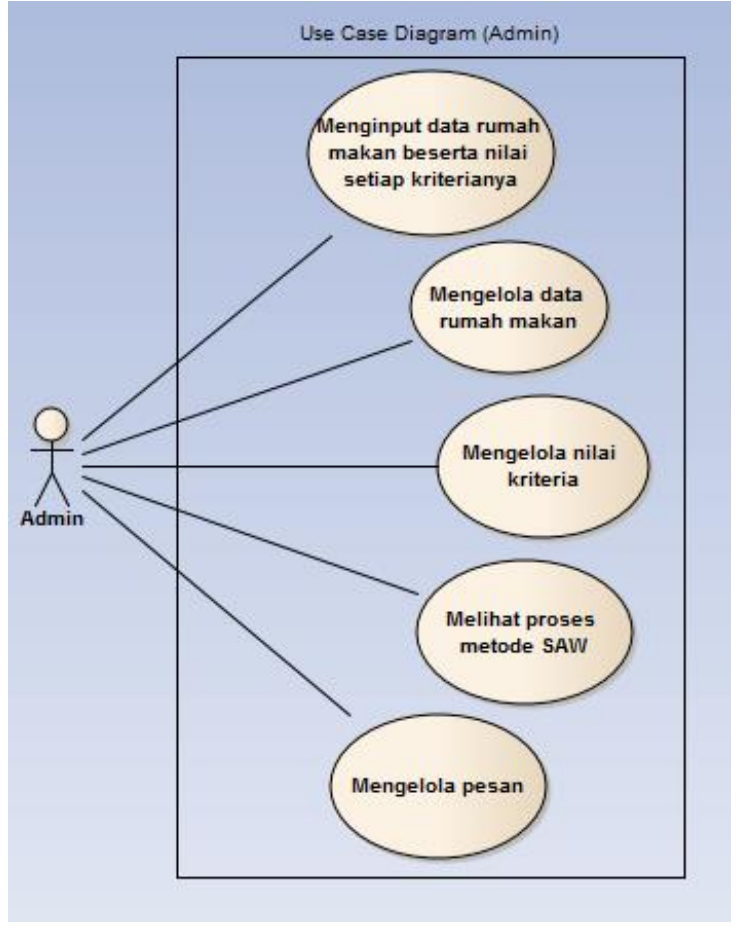

Picture 2. Use Case Diagram (admin)

While, the Picture 3 below is the use case diagram (user) that describes user capabilities in the system.

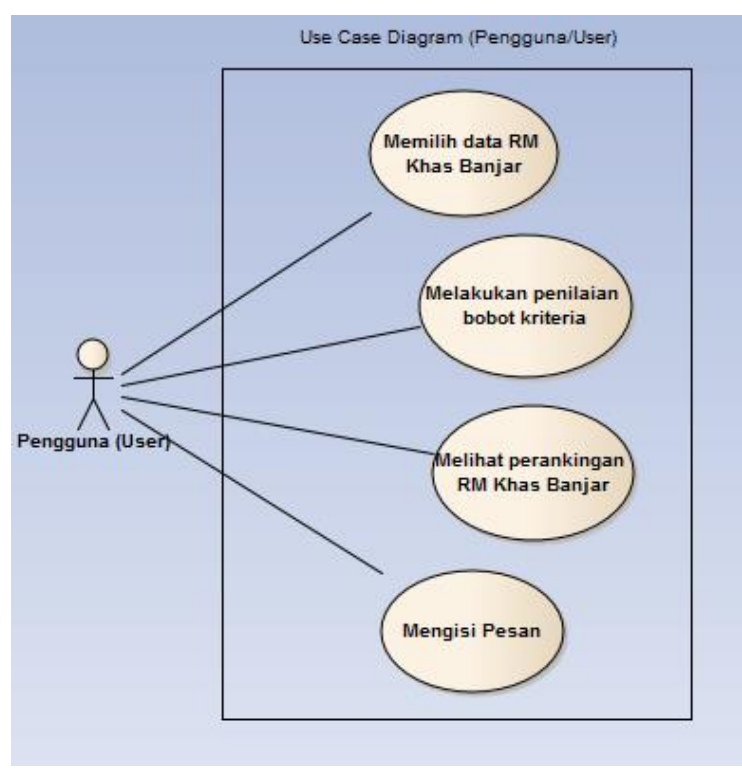

Picture 3. Use Case Diagram (User)

\subsection{Interface Design}

I. Login Page

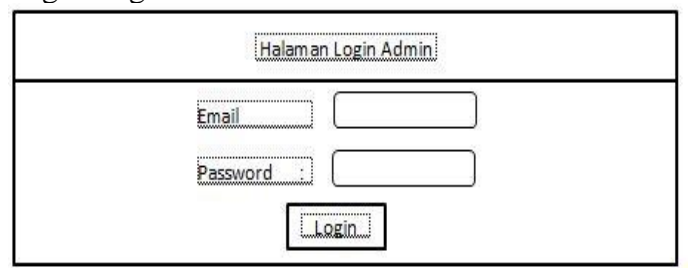

Picture 4. Login Page Design 
2. Admin Menu Page

\begin{tabular}{|c|c|c|}
\hline HEDOER & & \\
\hline lo: & & Logout \\
\hline MaIN CoNTEU: & & \\
\hline Dashboard & \multirow{5}{*}{ Pagetert: } & \\
\hline input Rumahmmakan & & \\
\hline Datarumahm Makan & & \\
\hline Merode saw & & \\
\hline Pesan Masuk & & \\
\hline
\end{tabular}

Picture 5. Admin Menu Page Design

3. User Menu Page

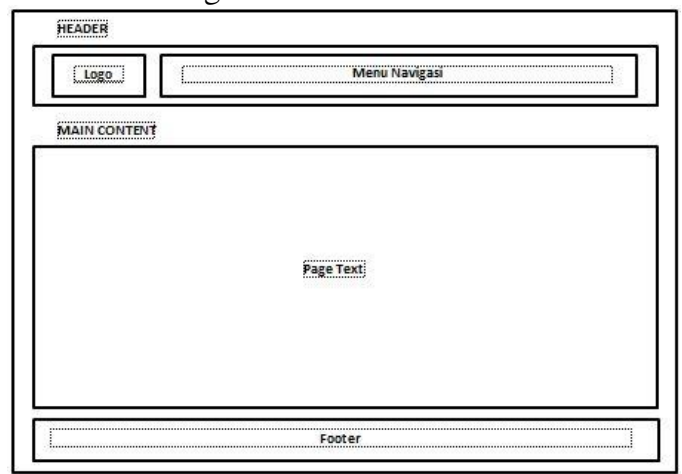

Picture 6. User Menu Page Design

\subsection{System Implementation}

\subsection{System Interface Implementation for Admin Page}

The implementation of system interface for admin page consists of several pages, namely:

I. Login page

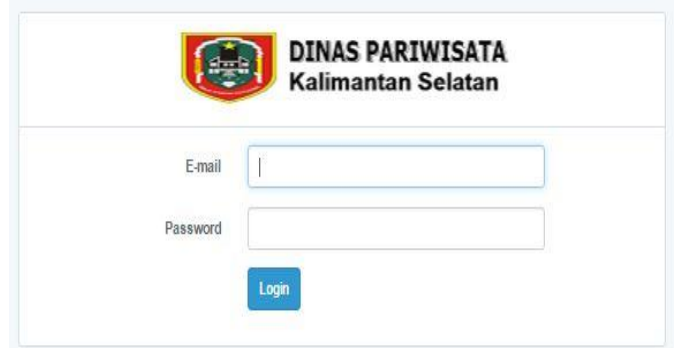

Picture 7. Login Page Implementation

2. Dashboard page

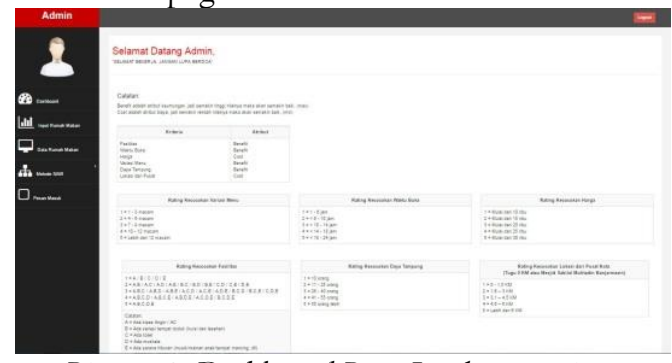

Picture 8. Dashboard Page Implementation
3. Restaurant Input Page

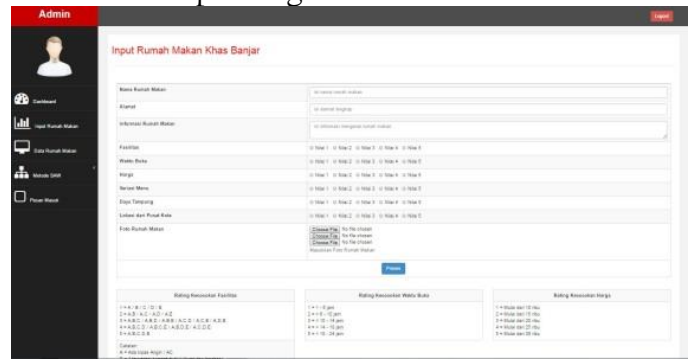

Picture 9. Restaurant Input Page Implementation

4. Restaurant Data Page

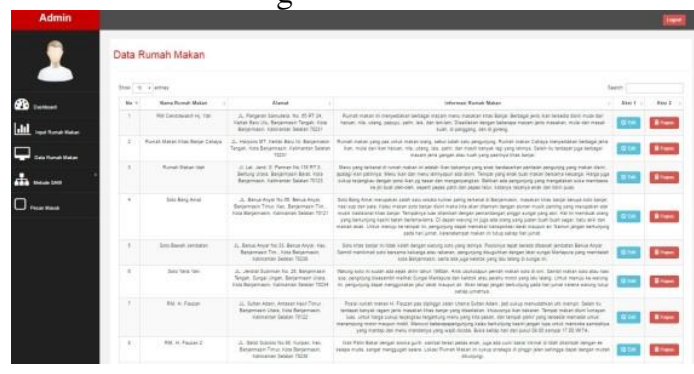

Picture IO. Restaurant Data Page Implementation

5. SAW Method Page

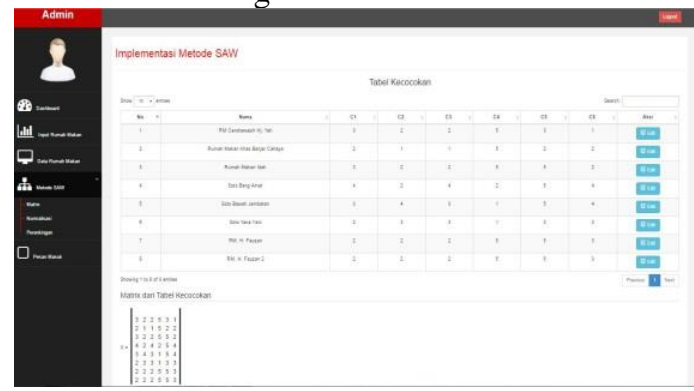

Picture II. Matrix Page Implementation

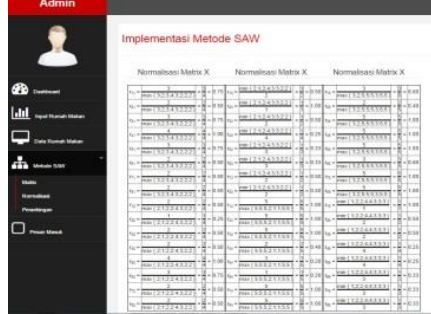

Picture I2. Normalization Page Implementation

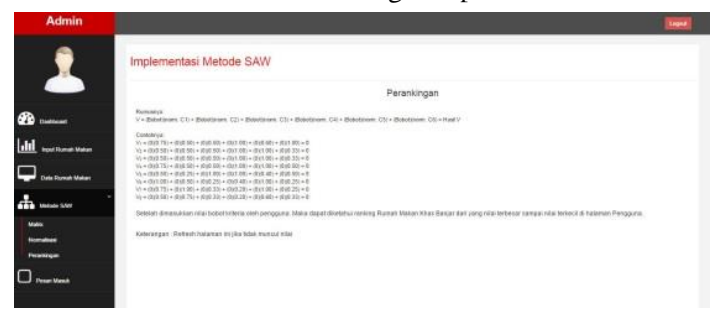

Picture I3. Ranking Page Implementation 
6. Inbox Page

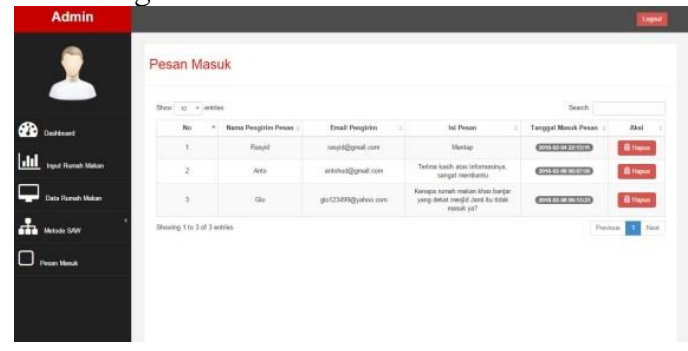

Picture I4. Message Page Implementation

\subsubsection{System Interface Implementation for User Page}

The implementation of system interface for user page consists of several pages, namely:

I. Home Page

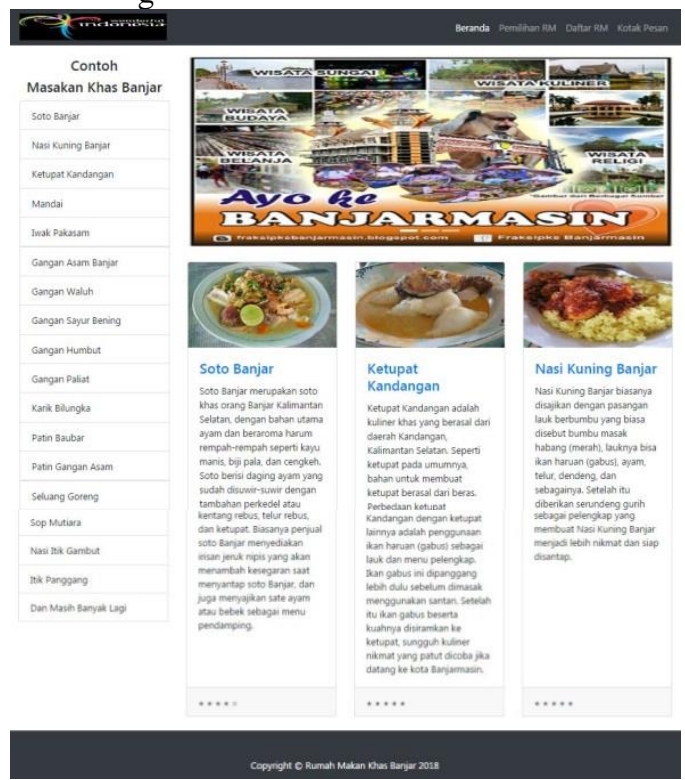

Picture I5. Home Page Implementation

2. Restaurant Selection Page

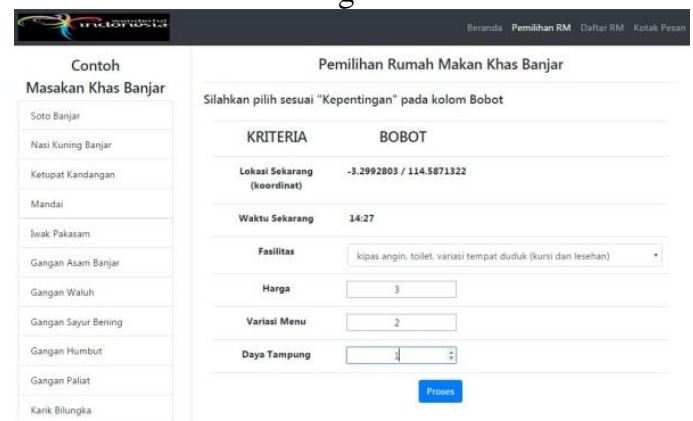

Picture I6. Restaurant Selection Page Implementation

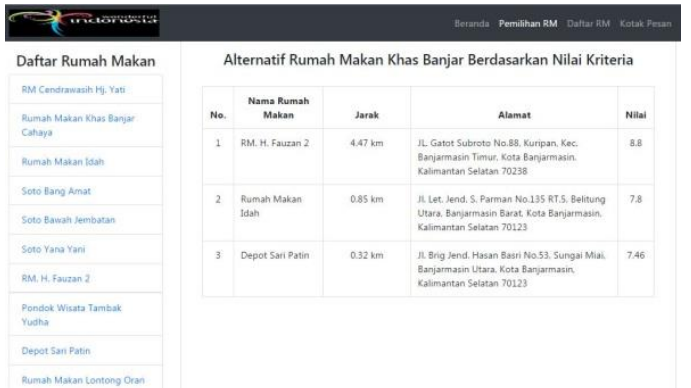

Picture 17. Selection Process Results Page Implementation

3. Restaurant Selection Page

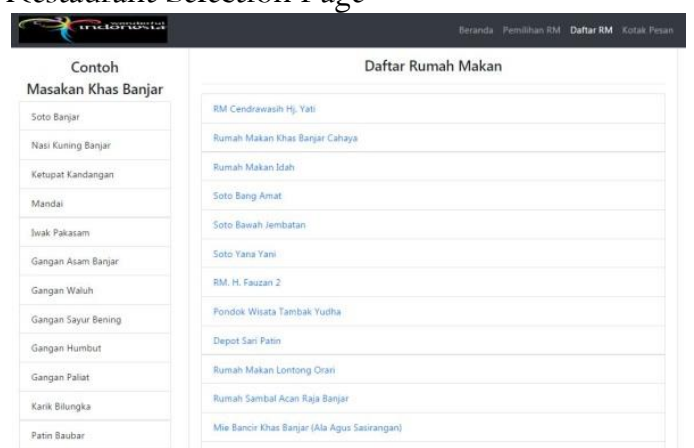

Picture I8. Restaurant List Page Implementation

4. Restaurant Information Page

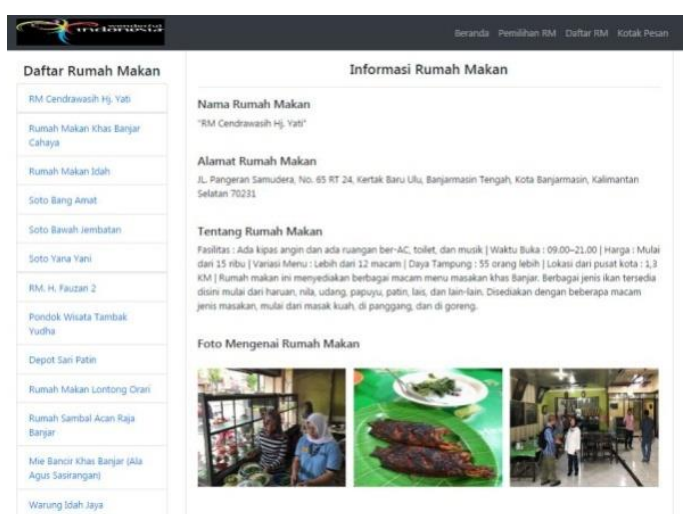

Picture 19. Restaurant Information Page Implementation

5. Mailbox page

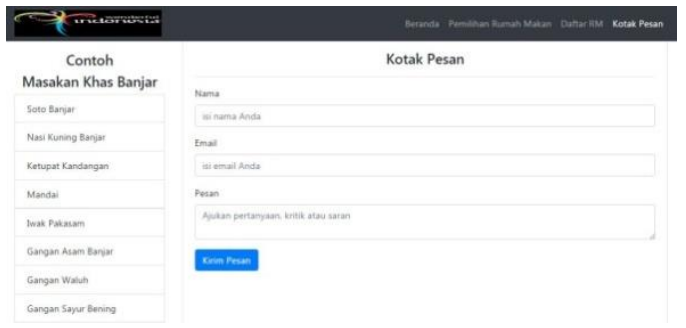

Picture 20. Mailbox Page Implementation

\section{Testing}

In this section, system testing was performed by analyzing the Calculation Score Interpretation (CSI) average from the results of user responses in 
general. In this test, researchers distributed questionnaires to 25 respondents from the Tourism Office, tourists, and prospective consumers about the suitability of the DSS for selecting Banjar restaurant.

The following are the score interpretation criteria based on intervals, namely:

- Score of 0\% - $19.99 \%=$ Very inappropriate

- Score of $20 \%-39.99 \%=$ Inappropriate

- Score of $40 \%-59.99 \%=$ Neutral

- Score of $60 \%-79.99 \%=$ Appropriate

- Score of $80 \%$ - $100 \%=$ Very appropriate

From 25 respondents who gave their assessment, the Calculation Score Interpretation (CSI) was $88.8 \%$. Thus, it is in the very suitable category to be used as a reference in facilitating Banjar restaurant selection.

\section{Conclusions}

After completing the research and observing the system, the conclusions of the Final Assignment report entitled "Decision Support Systems for Selecting Banjar Restaurant in Banjarmasin City Using Simple Additive Weighting Method" are as follows:

I. This system can facilitate users namely tourists and prospective consumers in selecting a Banjar restaurant in Banjarmasin City. In this case, DSS only provides alternative decisions and the user makes his/her decision.

2. This system also provides information about Banjar restaurants, so that users can find information about restaurants. User can utilize this system by inputting the weight value on each criterion. Then, it will provide a list of Banjar restaurants from the highest to the lowest.

3. The SAW (Simple Additive Weighting) method can help making decision in selecting a Banjar restaurant based on the existing criteria. From the analysis results of the Calculation Score Interpretation (CSI) average of users' responses results in general, the Tourism Office, tourists, or prospective consumers, stated that the system is very suitable to be used as a reference in selecting a Banjar restaurant in Banjarmasin City, with an $88 \%$ CSI.

\section{Acknowledgment}

This article is extracted from the results of joint research between lecturers and students under undergraduate thesis, so we are indebted to the university, especially to the information technology study program that has provided facilities and moral support.

\section{References}

Afnarius, S., Ningsih, V. M., \& Frihandana, D. (20I4). Pembangunan Aplikasi Wisata Kuliner Sumbar Berbasis. Prosiding Seminar Ilmiah Nasional Komputer Dan Sistem Intelijen (Kommit 20I4.) 354-360. Depok: Universitas Gunadarma.

Keen, P., \& Morton, S. (1978). Decision Support Systems: An Organizational Perspective. Massachusetts: Addison-Wesley.

Kusumadewi, S. (2006). Fuzzy Multi-Attribute Decision Making (Fuzzy MADM). Yogyakarta: Graha Ilmu.

Muliady, A., Thurovin, M., Gunawan, R., \& Ashari. (2013). Analisis Dan Perancangan Aplikasi Database Berbasis Web Untuk Sistem Informasi Komunitas Di Binus. Jakarta: Binus.

Rijani. (2015). Analisis Pasar Pariwisata Kalimantan Selatan Tahun 20I4. Banjarmasin: Dinas Pemuda Olahraga Kebudayaan dan Pariwisata Provinsi Kalimantan Selatan.

Sugiyono. (2008). Metode Penelitian Kuantitatif kualitatif dan R\&D. Bandung: Alfabeta. 
ISSN 2580-2135 